\title{
A ARTE literaria Na OBRA DE TITO LIVIO
}

\author{
Alice Cúnico Machado Fonseca \\ U.S.P. \\ RESUMO
}

Livio é o criador de uma prosa nova, de fisionomia épica e naturais reflexos de poesia. Com Vergflio es o heró representativo da Roma augistea, é a voz mais vasta de sete séculos de história, onde se fundem a epopéia, a lfrica, a elegia e o drama. Sua obra, Annales, como o Autor os chamou, o Ab urbe condita libri, denominaçāo posterior, nāo é um compeñio de moral ou de política ou de religiāo, mas o fluir do drami da vida, da ação, das cenas dos quadros que perpassam sob nossos alhos. Neles, o narrador desaparece completamente em funçāo do artista: o intérprete surpreende as almas no seu estado mais in. timo, procura estender o olhar além das contingèncias momentâneas. $O$ mérito do escritor e historiador Ĺvio está na capacidade de transformar os preceitos retóricos num toque de arte de modo a atingir um efeito particular. apresentando fatos e personagens num foco mais vivo. Sua característica primordial é a simplicidade grandiosa com que faz vibrar as paixōes que animam as personagens e movimentam as multidōes; é a capacidade de descrever com clareza e eficácia, num estilo rico e fluente; é a vivacidade expressiva com que cria certos efeitos cromáticos no discurso, sem degenerar na declamação.

Originário de Pádua, uma cidade louvada pela austeridade e modéstia de costumes, e conhecida pelos nobres sen. timentos republicanos, Lívio viveu um periodo tempestuoso: a morte de Júlio César, as proscriçōes dos triunviros, entre os quais morreu Cícero, o fim trágico de Bruto e Cássio, após a batalha de Filipos, as ameaças de Antônio, a vitória de Áccio ... passou incólume entre os tumultos e os incêndios da guerra civil, mas ficou exposto aos perigos, dos quais a muito custo se salvaram Vergílio e Horácio. Deu, no entanto, sua sincera adesão às últimas e infelizes lutas pela liberdade. 
Sua atividade literária explica-se no início no campo da filosofia e da retórica. Escreveu diálogos histórico-filosóficos e alguns livros de argumentos filosóficos, pelos quais Sêneca o colocou após Cícero e Poliāo. A influência dos estudos da adolescência e do ambiente em que viveu, acres. cia-se uma admiração incomum por Cícero que se estendia não somente ao orador, mas às suas concepçōes políticas. São termos seus:

"Si quis tamen uirtutibus uitia pensarit, uir magnus ac memorabilis fuit, et in cuius laudes exseguendas Cicerone laudatore opus fuerit" (frag. .L CXX). "Se alguém porém quiser contrapesar virtudes e vícios, ele era grande e digno de lembrança, e para fazer-lhe o elogio seria preciso um Cícero".

Alguns críticos vêem na obra de Lívio a encarnação do ideal da história, segundo o pensamento de Cicero. Este, de fato, considerava que à literatura latina faltava ainda o gênero da história "opus oratorium maxime"2. Provavelmente aludia a uma história geral e completa e não relativa a um único período de Roma; a uma história que nāo fosse árida exposiçāo eruđita, nem uma colheita de curiosidades, mas celebração eloqüente de feitos, mostra da vida; obra esta que somente um orador podia confiar à imortalidade.

Livio, sem dúvida, encontrava-se em Roma, quando deu início a seu grande trabalho, pois desde os primeiros livros fala-nos dessa cidade e de seus arredores de modo a não deixar dúvidas de que se tratava de coisas que estavam sob sua mira.

Sua obra, de singular extensão, cento e cinquenta livros dos quais chegaram até nós 35, abrange toda a história de Roma, das origens até a morte de Druso, na Germânia. O título devia ser "Ab urbe condita libri" como se lê nos códigos antigos, embora o próprio Lívio os tenha chamado "Annales", provavelmente năo tanto para indicar o título quanto o gênero.

O objetivo a alcançar com a obra é nítido na introdução que a precede. Pretendendo distrair o próprio espírito da contemplação dos males presentes, aplicou-se ao estudo da história antiga, com o desejo de elevar à memória do maior povo da terra, um monumento que fosse digno de sua fama:

1 Titl Livil fracmenta, In: TITO LIVIO. Opora. Intr. vrs. adn. J.B.L. Crevier. Verona, Bassanl Ed., 1821. A traducáo dos textos latinos, exceto do Pref́́clo da Histoiro Romaine, Elo da eutora.

2 CICERO. Do Logibus I, 5 
Ceterum aut me amor negotil suscepti fallit, aut nulla unguam res publica neca maior nec sanctior nec bonis exemplis ditior fuit, nec in quam ciuitatem tam serae auaritia luxuriaque immigrauerint, nec ubi tantus ac tam diu paupertati ac parsimonae honos fuerit. Adeo quanto rerum minus, tanto minus cupiditatis erat. (Praef. 11)

"Aliás ou me engana o amor ao trabalho que empreendo, ou nenhuma outra república, jamais, foi maior ou mais santa ou mais rica de bons exemplos; nem houve cidade na qual a cobiça e a luxúria tivessem penetrado tão tarde, nem onde houvesse sido tão grande por tanto tempo, a honra da pobreza e da parcimônia."3

Tito Livio não expõe em modo sistemático os seus princípios historiográficos, como o fizeram outros historiadores da antiguidade greco-latina. Seus critérios podem se deduzir aqui e acolá em toda sua obra. Embora não se possa excluir que vislumbrou as mais variadas concepçōes de história, liga-se quase exclusivamente com a precedente historiografia nacional, desde as origens, de caráter sagrado, e permitiu que a tradição revivida com espírito religioso fosse considerada inatingivel, mesmo quando pareciam justificadas as dúvidas sobre sua autenticidade:

Quae ante conditam condendamue Vrbem poeticis magis decora fabulis quam corruptis rerum gestarum monumentis traduntur, ea nec adfirmare nec refellere in animo est. Datur haec uenia antiquitati ut miscendo humana diuinis primordia urbium augustiora faciat." (Praef. 6)

"As glórias anteriores à fundação ou à idéia de fundação da Cidade, transmitidas mais por fábulas poéticas do que por documentos seguros de atos praticados, nāo tenho a intenção nem de confirmá-las nem de refutá-las. Conceda-se à Antiguidade que, unindo homens e Deuses, torne mais augustos os primórdios das cidades".

Satisfazia assim o desejo de Augusto de glorificar Roma na História assim como Vergilio a glorificara na Epopéia.

Alma entusiasta de orador e poeta, Livio não se preocupou em corrigir erros, nem submeter a exame crítico as fontes de que dispunha em número notável. Encontrou as causas das vitórias e da grandeza de Roma nas suas sábias

3 TITO LIVIO. Histoire romaine. Texte et. par J. Bayet. Parls, Les Belles Lettres. 1952. Os trechos traduzldos do Prefácio săo transcritos da ANTOLOaIA billingue de escritores :atinos 1: história. Sło Paulo. FFLCH UBP. 1987. 
leis e nos homens que as respeitaram, revivendo diante dos Romanos degenerados as virtudes dos antigos e estimulando-os a proceder como seus antepassados, pois que a incipiente decadência estava contida na corrupção:

"Ad Illa mihi per se quisque acriter intendat animum, quae uita, qui mores fuerint, per quos viros, quibusque artibus domi militiaeque et partum et auctum imperium sit; labente deinde paulatim disciplina velut desidentes primo mores sequatur animo, deinde ut magis magisque lapsi sint, tum ire coeperint praecipites, donec ad haec tempora, quibus nec vitia nostra nec remedia pati possumus, perventum est" (Praef. 9).

"Penso que cada um, por si mesmo, deve interessar-se por aquilo que foi a vida, que foram os costumes, que foram os homens através dos quais, e as artes pelas quais na paz e na guerra, foi o Império criado e dilatado. Afrouxando-se a seguir, paulatinamente, a disciplina, pode-se acompanhar, com o espírito, primeiro como que uma degeneração dos costumes; em seguida, como se afrouxaram cada vez mais, entāo começaram a mergulhar no abismo, até chegarmos a estes tempos, em que não podemos suportar nem os nossos vícios nem os seus remédios".

Assim sendo, firma-se histórico-moralista, desenvolve a teoria moral das "circunstâncias", herdada dos predecessores. Um exemplo:

No relato das guerras Samitas ou da Macedônia, as causas que produziram a vitória foram múltiplas, algumas das quais permanentes: a uirtus romana, a Fortuna, os mores, os uiri e as artes dos próprios Romanos além de outras variantes fornecidas pelos povos contra quem guer. reavam.

Livio jamais se preocupou em reencontrar o herói ou um valor sobre humano, analisa e pondera as circunstâncias e, a seu critério, daquelas extraiu os elementos, cujas causas e efeitos serviam para solucionar melhor o fato. Deste modo concebe a história da Urbe: nada acontece ou se desenvolve sem que os motivos substanciais de um fato sejam acompanhados de outros secundários que ajudam e determinam a atuação.

As lutas para a igualdade das duas classes, patrícia e plebéia são tratadas por Lívio em diversas etapas: desde a formação de um corpo eleitoral da plebe, até a constituição 
de um exército Romano. Explicaçōes são dadas pelos oradores senatoriais ao povo, de modo a deixar evidente as razões da resistência dos patrícios; esforços pelos oradores do povo, para mostrar por que era justa a concessão da igualdade e quais os motivos que permitiam fosse mantida a petição. A justiça de tais solicitações não teria sido suficiente, sem os argumentos circunstanciais que dobraram os Optimates. O Autor, no $2 .^{\circ}$ livro, nos dá uma série de precedentes que a preparam.

Salústio, provavelmente, teria estruturado o fato de modo diverso: pelo retrato da personagem principal, a exposição das condiçóes internas de Roma, reunindo todos os recursos e os momentos de luta em torno daquela figura.

Esta teoria histórico-filosófica de Livio mantém-se viva e preferivel em nossos dias, entre as múltiplas cogitadas, no tempo antigo e no moderno, pelos historiadores e filósofos.

Num periodo de sete séculos, tão fecundo em acontecimentos e sacudido de verdadeiras e próprias revoluções, os heróis de Livio quase não mudam: são as mesmas virtudes, da mesma frugalidade, do mesmo desinteresse, do mesmo patriotismo, da mesma eloquiência. Sua história, no entanto. não permanece objetiva. Se a matéria lhe convém, o historiador repousa seu ânimo na contemplação do passado, anima-a com o sopro da eloquiência e torna-a eminentemente subjetiva, modificada, sublimada na esfera da arte. Assim procedendo, liberta-se do íncubo dos males presentes e propõe-se em exercitar uma real eficácia nos seus concidadãos, colaborando com a reforma social e moral que Augusto se propunha fazer triunfar. Daí seu conceito: "a vantagem maior da história é poder olhar como num quadro luminoso a ensinamentos de toda espécie. A história, magistra uitae, poderá inspirar a sua conduta no seu interesse e no de estado; da história poderá aprender o de que se deve fugir, enquanto vergonhoso para se iniciar e vergonhoso para se cumprir". (Cf. Praef. 10)

Estas foram as idéias morais, religiosas e políticas de Livio, não suas pessoais, mas de uma elite, que permanecia fora e acima de partidos e tinha verdadeiro amor pela pátria. Estímulo dessas idéias, o sentimento da arte.

Um temperamento fantástico e poético como Livio nāo podia contentar-se do ofício sombrio de simples narrador; tinha a necessidade de iluminar com belas formas os fatos da História Romana, animá-la com os sentimentos. Por iss, vivia na idade de Augusto, justamente denominada idade áurea. 
Sua história, pois, é antes de tudo uma obra de arte, um vasto panegírico artístico, animado por um vivo sentimento épico: num toque mágico de sua palavra, os fatos se animam, as personagens vivem e falam, a multidão avuita e se manifesta. Não somente narra, mas dramatiza. As paixões adquirem um poder que merece enquadrar-se nos atos de um drama, mais que nos capítulos de uma história. A matéria humana, em suas mãos, se flexibiliza, não como deseja o rígido historiador, mas como deseja o artista. O desenvolvimento de uma batalha não é aquele que Livio nos apresenta, mas não se pode negar que os chefes e as massas agem como a natureza deseja que o homem aja naqueles trágicos momentos. Eis a descrição que o historiador nos oferece da situação em Roma à notícia de que Anibal está a oito milhas da cidade:

Roman Frefellanus nuntius, diem noctemque itinere continuato, ingentem attulit terrorem: tumultuosius, quam quod allatum erat, concursus hominum affingentium uana auditis totam urbem concitat. Ploratus mulierum non ex privatis solum domibus exaudiebantur, sed undi que matronae in publicum effusae circa deum delubra discurrunt, crinibus passis aras verrentes, nixae genibus, supinas manus ad caelum ac deos tendentes orantesque et urbem romanam e manibus hostium eriperent matresque Romanas et liberos parvos inviolatos servarent. (L. XXVI, 9)

"Um mensageiro de Fregelas trouxe a Roma, em marcha ininterrupta de um dia e uma noite, um terror imenso; num tumulto maior do que a notícia justificava, uma aglomeração de homens, que acrescentava dados originários, abalou toda a Cidade. Não só das residências se ouviam lamentos das mulheres, mas também, em público, matronas se espalhavam percorrendo os templos, varriam com os cabelos soltos os altares, erguiam, ajoelhadas, as mãos para o céu e aos deuses, implorando que arrebatassem Roma às mãos do inimigo e preservassem invioladas as matronas romanas e seus filhos pequeninos. ".

O que surpreende é a precisāo como são colhidos os sentimentos de uma coletividade, recorrendo à variação de formas gramaticais, narrativas e pictóricas. De início, chama a atenção a posição das palavras na frase. $O$ advérbio "tumultuosius", no inicio do periodo, dá um relevo particular à palavra sobre a qual Livio quer insistir. E como um prelúdio 
da descriçāo seguinte; os particípios presentes e passados, para dar maior concisão, permitem uma maior visualização, intensificando e tornando mais eficaz a representação. Assim, aras uerrentes, orantes, tendentes, passis nixae unem-se eficazmente a passis, para melhor representar a atitude desesperadora e dolente da multidão de mulheres; o arcaísmo deum por deorum dá uma colorido poético e solene nos momentos de maior emoção. A preocupação do detalhe:effusae in publicum, nixae genibus, supinas manus, conservam todo o seu relevo e concorrem para a formaçāo de um quadro realista. Os aspectos são apresentados assindeticamente para dar maior dinâmica e vivacidade ao quadro, intensificada até a impressāo de agitaçāo pelo ritmo quebrado e descontínuo de frases longas e curtas:, passis aras uerrentes e nixae genibus.

Onde porém as virtudes literárias de Livio săo mais visíveis e admiradas, é nos discursos. Contrário aos retratos diretos de seus personagens, apresenta-os em seu estado d'alma no ato e particularmente na forma viva de um discurso como é próprio da historiografia antiga, que desde o início, colora pensamentos e sentimentos dos atores, adivinhando-os, quando não os conhece. De caráter retórico, nunca muito longos e por isso limpidos na sua construção, apresentam as formas retóricas tradicionais: interrogaçōes, exclamações, antiteses, hipérbole, etc. O tom, no entanto, é novo por terem uma função artística, enquanto se delineiam com maior força, figuras e cenas e se exprimem na concretude de uma personagem, os sentimentos e os interesses que animam e movem os fatos naquela determinada circunstância. Por isso, Lívio prefere os discursos diretos aos indiretos, sobretudo nos momentos culminantes da ação ou nas personagens mais amplamente retratadas.

Com quanta arte, Livio soube colher, no pequeno discurso de Lucrécia, os momentos essenciais da situaçāo e ela. borar uma análise psicológica das mais bem acabadas da luta terrivel que aflige o coração de Lucrécia, sob o peso de seu orgulho ferido.

Conta Livio (L. I, 57-59) que, durante o sitio de Ardea, Sexto Tarquínio e os demais príncipes costumavam reunir-se em alegres pândegas. Um dia o assunto recaiu sobre suas mu. lheres. Cada um celebra a virtude da própria e Colatino convida os amigos a constatar quanto Lucrécia se avantajava às outras. A comitiva parte. Em Roma, encontram as princesas dedicadas aos banquetes; em Colácia, no entanto, surpreendem Lucrécia, no âmago da casa, comandando as criadas na dobragem da lā. A leveza e a virtude da esposa de Colatino inflamam Sexto de uma obsessiva libido. Em poucos 
dias, volta a Colácia e Lucrécia, nada suspeitando, recebe-os afavelmente e hospeda-o; à noite, recolhidos todos, Sexto empunha a espada, abeira-se de Lucrécia adormecida e com a mão esquerda lhe oprime o peito, ameaçando-a de que, se não cedesse, após matá-la, colocaria a seu lado um escravo nu e degolado. Lucrécia consente, persuadida de que nāo convinha morrer, antes de desmoralizar a calúnia. Após o delito, Sexto volta ao campo. Lucrécia, no entanto, manda um mensageiro aos pais e ao marido, que se precipitam a Colácia com os amigos Bruto e Valério.

O texto, parece-nos, dispensa interpretações à luz de fontes poéticas trágicas, porque o estilo trágico não é um fato episódico, mas diz respeito a toda a historiografia liviana, mesmo se em alguns casos é mais evidente. Observa-se que, na construção da estória por cenas, Livio seguiu um preceito aristotélico, ou seja, manteve uma ação única completa, tendo início, meio e fim.

O historiador soube condensar a matéria, expressando potentemente e com linear simplicidade seja o drama de Lucrécia encerrado nos termos moesta e lacrimae abortae seja aquela do pai e do marido concentrado no estilema conclamant uir paterque. $O$ discurso direto de frases breves, vibrantes, acentua a indignação de Lucrécia, de início emocionada à vista do pai e do marido; posteriormente resoluta e altiva, com palavras decisivas e rápidas, desvela seu pensamento como se o golpe do punhal a desnudasse no mesmo instante que era desferido: Vos ..... exemplo vivet. A ênfase aliada à veemência com que se dirige aos seus si uos viri estis estimulando a dignidade e hombridade, parece destinada a oferecer modelos de conduta para o homem comum, rmostrando como a grandeza nacional não pode ser reconquistada e mantida sem uma sã moralidade.

Uma história tão ampla, concluída num momento de esplêndida civilização e cultura impar, não podia ser narrada à revelia do gosto refinado dos leitores e das novas concepçōes morais e politicas. Livio aderiu aos novos ideais estéticos e, nesta adesão, sua obra encontra justificativa diante dos contemporâneos e dos pósteres, pois o autor soube unir à sensibilidade do poeta, a força persuasiva do orador. Baste este último exemplo para evidenciar as virtudes narrativas do autor em inúmeras passagens de sua história, amenizando o possivel tédio de leitura duma obra monumental e maçante. 


\section{REFERENCIAS BIBLIOGRAFICAS}

1 ANDRE, J.M. \& HUS, A. LHistoire à Rome. Paris, Presses Universitaires de France, 1974.

2 ANTOLOGIA bilíngule de escritores latinos I: história. Săo Paulo, FFLCH USP, 1987.

3 BORNECQUE. Tite Lve. Paris, 1833.

4 COECHIA, E. Tito livio e Polibio. Roma, Studio Bibliografico, 1980.

5, MARCHESI, C. Storia della letteratura latina. Messina, 1940, v2.

6 RIEMANN, G. Etude sur la langue et la grammaire de Tite Live. 2. éd. Paris, 1885.

7 TITO IIVIO. Histolre romaine. Texte ét. par J.Bayet. Paris, Les Belles Lettres, 1952.

$8 \longrightarrow$ Opera. Intr. vrs. adn. J.BICrevier. Verona, Bassani Ed. 1821. 